ВИКОРИСТАННЯ МІЖНАРОДНИХ
НАУКОМЕТРИЧНИХ БАЗ ААНИХ
WЕВ ОF SСІЕNСЕ ТА SСОРUS АІЯ
НАУКОВИХ АОСІІЖЕНЬ В
АГРАРНИХ ЗАКЛАААХ ВИЩОЇ
ОСВІТИ $^{\odot}$

ВИКОРИСТАННЯ МІЖНАРОАНИХ WEB OF SCIENCE TA SCOPUS АЛЯ НАУКОВИХ ДОСЛІЖЖЕНЬ В АГРАРНИХ
B. A. МАЗУР,

кандидат сільськогосподарських наук, доцент, ректор Вінницького національного аграрного університету,

К. В. МАЗУР, кандидат економічних наук, доцент, завідувач кафедри аграрного менеджменту,

Г.В. ПАНЦИРЕВА, кандидат сільськогосподарських наук, старший викладач кафедри лісового, садово-паркового господарства, садівництва та виноградарства, Вінницький національний аграрний університет (м. Вінниця)

Визначено необхідність розвитку в аграрних університетах наукометричних досліджень та проаналізовано світові бібліометричні платформи Web of Science та Scopus. Установлено доиільність проведення наукових досліджень із застосуванням наукометрії на базі аграрних закладів вищої освіти. Досліджено критерії та стандарти, які необхідні для якісного використання наукометрії в наукових дослідженнях. Зарезультатами досліджень основними критеріями добору наукометричних платформ та їх показниками було обрано охоплення украӥнських наукових видань та публікаиій, точність даних, у тому числі правдивість показника цитованості наукової публікації, фільтрування надлишкових даних, можливість отримання усіх відомостей про публікащії за автором. Досліджено загальні характеристики наукометиричних баз даних Web of Science та Scopиs (мову інтерфейсу, обсяг даних, джерело даних, наукометричні показники) й визначено основні, в яких враховано наявність розширеного пошуку, можливість комунікаціїнауковиів, ідентифікащію науковия, можливість посилання на наукову публікацію. Після аналізу спеціалізованої літератури та сайтів розробників міжнародних наукометричних баз даних для подальшого трунтовного дослідження, окреслено шллх надходження публікачій до читачів у Інтернет-просторі, щчо пов'язаний з активною участю авторів у розміщенні наукових статей у таких інформаџійних системах, як Google Scholar, ORCID, Research ID. Установлено, що в аграрних навчальних закладах наявність інформачійноаналітичної діяльності в умовах комплексних змін інформаџійного середовища трансформує навчальну установу в центр соиіальних комунікаиій, що є важливим для проведення наукових досліджень.

Ключові слова: Web of Science, Scopus, наукометричні бази даних, індекс цитування, наукові публікації.

Табл.: 3. Літ.: 12.

\title{
USE OF INTERNATIONAL SCIENTIFIC DATA BASES WEB OF SCIENCE AND SCOPUS FOR SCIENTIFIC RESEARCH AT AGRICULTURAL HIGHER EDUCATION INSTITUTIONS
}

Candidate of Agricultural Sciences, Associate Professor of the Department of Plant Production, Selection and Bioenergetic Crops, Rector of Vinnytsia National Agrarian University, Candidate of Economic Sciences, Associate Professor, Head of the Department of Agrarian Management 
PANTSYREVA Hanna, Candidate of Agricultural Sciences, Senior Lecturer of the Department of Forestry, Landscape Gardening, Horticulture and Viticulture of Vinnytsia National Agrarian University

(Vinnytsia)

The necessity of development of scientific research in agrarian universities was substantiated and the world's bibliometric platforms Web of Science and Scopus were analyzed. The expediency of conducting scientific researches with the use of science-based research on the basis of agricultural institutions of higher education is established. The criteria and standards that are necessary for the qualitative use of scientific data bases in scientific research were investigated. According to the results of the research, the main criteria for the selection of science-computer platforms and their indicators were determined: the coverage of Ukrainian scientific periodicals and publications, the accuracy of data, including the truthfulness of citation, filtering of excess data, the possibility of obtaining all information about the publication and the author. The general characteristics of the scientific databases of Web of Science and Scopus (interface language, data volume, data source, scientific metrics) are investigated and the main ones among them are determined, which include the availability of advanced search, the ability to communicate with scientists, the identification of a scientist, the possibility to link with a scientific publication. After analyzing specialized literature and sites for the development of international sciencecomputer databases for further thorough research, the way of passing publications to readers in the Internet space is described, which is related to the active participation of authors in the placement of scientific articles in such information systems as Google Scholar, ORCID, Research Id. It was established that in agrarian educational institutions the availability of informational and analytical activity in conditions of complex changes of information environment transforms the educational institution into a center of social communications, which is important for conducting scientific research.

Key words: Web of Science, Scopus, наукометрические базы данных, индекс цитирования, научные публикации.

Tabl.: 3. Ref.: 12.

\title{
ИСПОЛЬЗОВАНИЕ МЕЖДУНАРОДНЫХ НАУКОМЕТРИЧЕСКИХ БАЗ ДАННЫХ ШЕВ OF SCIENCE И SCOPUS ДЛЯ НАУЧНЫХ ИССЛЕДОВАНИЙ В АГРАРНЫХ УЧЕБНЫХ ЗАВЕДЕНИЯХ ВЫСШЕГО ОБРАЗОВАНИЯ
}

\author{
МАЗУР Виктор Анатольевич, \\ кандидат сельскохозяйственных наук, \\ доцент кафедры растениеводства, селекции и биоэнергетических культур, \\ ректор Винницкого национального аграрного университета, \\ МАЗУР Екатерина Васильевна, \\ кандидат экономических наук, доцент, \\ заведующая кафедрой аграрного менеджмента, \\ ПАНЦЫРЕВА Анна Витальевна, \\ кандидат сельскохозяйственных наук, \\ стариий преподаватель кафедры лесного, садово-паркового хозяйства, \\ садоводства и виноградарства \\ Винницкого национального аграрного университета
} (2. Винница)

Определена необходимость развития в аграрных университетах наукометрических исследований и проанализированы мировые библиометрические платформы Web of Science u Scopus. Установлена иелесообразность проведения научных исследований с применением наукометрии на базе аграрных высших учебных заведений. Исследованы критерии и стандарты, которые необходимы для качественного использования наукометрии в научных исследованиях. По результатам исследований основными критериями отбора наукометрических платформ и их показателями были избраны: охват украинских научных изданий и публикаций, точность данных, в том числе правдивость показателя циитируемости научной публикации, фильтрации избыточных данных, возможность получения всех сведений о публикаиии по авторам. Исследованы общие 
http://efm.vsau.org/

характеристики наукометиричних баз данных Web of Science и Scopиs (язык интерфейса, объём данных, источник данных, наукометрические показатели) и определены основные, в которых учтены наличие расширенного поиска, возможность коммуникации учёных, иденттификация учёного, возможность ссылки на научную публикацию. После анализа спечиализированной литературы и сайтов-разработчиков международных наукометрических баз данных для дальнейшего обстоятельного исследования очерчены пути поступления публикачий к читателям в Интернетпространстве, связанные с активным участием авторов в размещении научных статей в таких информационных системах, как Google Scholar, ORCID, Research ID. Установлено, что в аграрных учебных заведениях наличие информачионно-аналитической деятельности в условиях комплексных изменений информачионной среды трансформирует учебное заведение в чентр сочиальных коммуникаций, что важно для проведения научных исследований.

Ключевые слова: Web of Science, Scopus, наукометрические базы данных, индекс цитирования, научные публикации.

Табл.: 3. Лит.: 12.

Постановка проблеми. Стрімкий розвиток науково-технічного прогресу, у тому числі і в аграрній сфері, а також впровадження інформаційних технологій кардинально підвищили можливості проведення наукових досліджень, які $\epsilon$ важливими як 3 практичного, так i 3 теоретичного погляду. Одним із основних завдань науковців на сучасному етапі розвитку сільськогосподарської науки є вдосконалення планування експерименту, широке використання комп'ютерних технологій, закладка серії дослідів із застосуванням методів фундаментальних досліджень із використанням міжнародних наукометричних баз даних Web of Science та Scopus [1].

У сучасних умовах аграрного виробництва України вагомий внесок належить науковим дослідженням, які базуються на світовому визнанні, а публікації в наукових журналах, що індексуються в міжнародних наукометричних базах даних Web of Science та Scopus, призведуть до можливості модернізації сучасної науки в аграрних закладах вищої освіти. На сьогодні в нашій державі вже існує досвід визначення науково-дослідних та інноваційних пріоритетів, проте дотепер дослідження вітчизняних науковців не враховували використання масштабних сучасних інформаційних потужностей для визначення результативності наукової діяльності. У зв'язку із цим залучення інформаційних технологій в аграрну сферу у поєднанні із використанням міжнародних наукометричних баз даних Web of Science та Scopus дозволить значно розширити науковий світогляд науковців [2].

Варто усвідомлювати, що публікація результатів лабораторно-польових досліджень у наукових виданнях, що індексуються в наукометрії Web of Science та Scopus, має стати перспективним трендом та активно розвиватись у колективах молодих учених, зокрема при виконанні наукових досліджень в агрономії. У таких наукових працях висвітлюються світові та вітчизняні основи досліджень, результати агрономічних дослідів 3 розкриттям методики планування й техніки проведення цих дослідів із розрахунком біоенергетичної та економічної ефективності. Значну увагу в таких публікаціях приділено проектуванню схем дослідів і плануванню в них вагомих результатів досліджень. Окремими частинами цих результатів $\epsilon$ методики проведення експериментальних робіт у дослідах та статистичної обробки результатів на новому науково-дослідницькому рівні [3].

Підвищення якості кадрового потенціалу позитивно впливає на трансформаційні процеси в науковій сфері нашої країни та світу в цілому. Отже, опрацювання цих питань становитиме вагомий внесок у вітчизняну науку в цілому, й, у першу чергу, у сільськогосподарську науку [4].

Аналіз останніх досліджень і публікацій. Наукові дослідження мають велике значення для розвитку університету: забезпечують якісну підготовку кваліфікованих фахівців, дають змогу поглиблювати міжнародну освітню та наукову діяльність, сприяють розвитку інноваційної діяльності. Якщо наукові агрономічні дослідження поєднати з виробництвом, вони дадуть поштовх для розвитку аграрної економіки. Таке поєднання сприятиме суспільному розвитку. Реалізація наукових досліджень у вищих аграрних навчальних закладах $є$ необхідною умовою підвищення їхньої конкурентоздатності у міжнародному науково-освітньому просторі. Університети, поруч 3 виконанням своєї основної функції - освітньої, займаються польовими дослідженнями та розробкою інновацій. Нині спостерігаємо поглиблення інтеграції освіти й аграрної науки в межах університетського сектору, що зумовлено зростанням значення наукових досліджень і підготовки агрономів-дослідників належного рівня [5]. 
Вивченням питань, що пов'язані з теоретичними аспектами наукометричних баз даних, займались провідні світові та вітчизняні науковці Л. Джорджіу, У. Каджикова, Б. Мартін, Дж. Хеуер, Г. Добров, Б. Маліцький, Л. Костенко, В. Рибачук, Д. Солов'яненко, А. Корецький, О. Мех та ін. $[1,3,5]$.

За даними досліджень установлено, що технології є одними з домінантних факторів, які мають визначальний вплив на розвиток як виробничо-економічного, так і соціального потенціалу країни. Розвиток аграрного виробництва базується на досягненнях таких сільськогосподарських наук, як рослинництво, землеробство, екологія, кормовиробництво та низки економічних наук. Численними дослідженнями встановлено, що академічна наука не вирішує конкретних виробничих або фінансових завдань в агросфері, проте наукові польові дослідження впливають на економічну та виробничу сфери через розвиток техніки, удосконалення технологій вирощування сільськогосподарських культур, покращення екологічного стану, збереження родючості грунтів тощо [6].

На сучасному етапі розвитку взаємозв'язок між наукою та аграрним виробництвом характеризується формулою: наука - це безпосередня виробнича сила. Це зумовлює необхідність забезпечення взаємозв'язку агровиробництва із науковими установами й аграрними навчальними закладами. Важливість дослідження в аграрній науці зазначеного взаємозв'язку підсилюється в умовах структурних перетворень економіки сільського господарства, а також забезпечення ії інноваційного розвитку. Інтегративна взаємодія аграрного виробництва, науки та аграрних закладів освіти дає позитивний ефект. Крім того, дослідженнями встановлено, що стимулювання розвитку інноваційних підприємств за підтримки держави стало одним з факторів розвитку національних економік у Китаї, Ізраїлі, Фінляндії. За даними Всесвітнього банку, у світі на освіту спрямовується в середньому 13\% державних витрат (для порівняння в Україні у 2017 р. на науку та освіту було витрачено 0,16\% ВВП або 621,5 млн грн на фінансування освіти та 2719 млн грн на фінансування Національної академії наук, при цьому частка підтримки суто університетської освіти у загальному науковому бюджеті України склала 10\%) [7].

Аналіз літературних джерел показав, що за індексом рівня освіти (Education Index) у 2016 p. Україна посідала 40-е місце з рівнем 0,803 (у більшості розвинених країн світу значення цього індексу перевищує 0,9); за індексом розвитку людського потенціалу (Human Development Index) 81-е місце із рівнем 0,747 [5]. Однак ці показники враховують лише кількість осіб, які мають освіту, а не іiї якість. За рейтингом національних систем вищої освіти (U21 Ranking of National Higher Education Systems), в якому враховуються ресурси (інвестиції з боку приватного та державного секторів), результати (наукові дослідження, наукові публікації, відповідність вищої освіти потребам національного ринку праці), зв'язки (рівень міжнародного співробітництва), середовище (державна політика та регулювання, можливість отримання освіти), Україна посіла 36-е місце з 50 країн із рівнем 47,7 (порівняно із максимальним значенням - 100) [6].

3 метою сприяння зростанню якості наукової та освітньої діяльності в аграрних університетах і визнанню досягнень вітчизняної науки Міністерство освіти і науки України впровадило підходи до стимулювання викладачів усіх ЗВО щодо опублікування наукових статей у провідних наукових виданнях, які входять до міжнародних наукометричних баз даних Scopus i Web of Science.

Формулювання цілей статті. Метою дослідження $\epsilon$ визначення основних переваг використання міжнародних наукометричних баз даних Web of Science та Scopus для наукових досліджень в аграрній сфері й надання пропозицій щодо пошуку даних та підбору видань для їх ефективного використання у дослідній роботі науково-педагогічних працівників аграрних закладів вищої освіти.

Завданням статті є обгрунтування необхідності застосування наукометричних баз даних Web of Science та Scopus під час проведення наукових досліджень у вищих аграрних навчальних закладах освіти з урахуванням інноваційних підходів, обгрунтуванням пріоритетів розвитку науки та виробництва в їхньому взаємозв'язку за допомогою використання зазначених наукометричних баз даних.

Теоретичною та методичною основою написання статті є праці іноземних і вітчизняних науковців, присвячені вивченню пріоритетів інноваційного розвитку науки з використанням наукометричних баз даних Web of Science та Scopus при проведенні наукових досліджень в аграрній сфері. У роботі використано загальнонаукові та спеціальні методи дослідження, а саме: системний, порівняння, абстрагування, синтез, аналіз, узагальнення, класифікація, статистичне оброблення інформації, групування, графічний аналіз та наукометричний. 


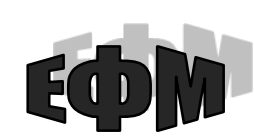

http://efm.vsau.org/

Інформаційну базу дослідження складали чинні законодавчі та нормативні акти України, постанови Кабінету Міністрів України, офіційні дані Державної Служби статистики України щодо наукової та інноваційної діяльності, а також дані, які представлено у міжнародних наукометричних базах даних Web of Science та Scopus [5, 9-12].

Виклад основного матеріалу дослідження. Web of Science (WoS) - провідна міжнародна реферативна база даних наукових публікацій, що дозволяє здійснювати пошук серед понад 18000 журналів і 150000 матеріалів конференцій (табл. 1).

База даних містить такі індекси - Science Citation Index Expanded (природничі науки), Social Sciences Citation Index (суспільні науки), Arts and Humanities Citation Index (мистецтво та гуманітарні науки), Emerging Sources Citation Index, Conference Proceedings Citation Index (матеріали конференцій), Book Citation Index (наукові книги) та ін. [4, 7].

Таблиия 1

Характеристика досліджуваних міжнародних баз даних Web of Science та Scopus

\begin{tabular}{|c|c|c|c|c|c|}
\hline $\begin{array}{l}\text { № } \\
\text { 3/II }\end{array}$ & $\begin{array}{c}\text { База } \\
\text { даних }\end{array}$ & $\begin{array}{c}\text { Інформація про } \\
\text { створення (рік, } \\
\text { компанія) }\end{array}$ & $\begin{array}{c}\text { Кількість } \\
\text { індексованих } \\
\text { журналів }\end{array}$ & Доступність & $\begin{array}{c}\text { Наявність } \\
\text { показника } \\
\text { (SNIP, імпакт- } \\
\text { фактор) }\end{array}$ \\
\hline \multirow[t]{4}{*}{1} & \multirow[t]{4}{*}{$\begin{array}{l}\text { Web of } \\
\text { Science } \\
\text { (WoS) }\end{array}$} & \multirow[t]{4}{*}{$\begin{array}{l}\text { 1880, } \\
\text { Elsevier }\end{array}$} & \multirow[t]{4}{*}{18000} & $\begin{array}{l}\text { Кількість } \\
\text { лених в БД стстав- } \\
\text { автора, організації }\end{array}$ & \multirow[t]{4}{*}{ Імпакт-фактор } \\
\hline & & & & $\begin{array}{l}\text { Пошук за ключовими } \\
\text { словами, по автору, } \\
\text { організації }\end{array}$ & \\
\hline & & & & h-індекс & \\
\hline & & & & Умови передплати & \\
\hline \multirow[t]{4}{*}{2} & \multirow[t]{4}{*}{ Scopus } & \multirow[t]{4}{*}{$\begin{array}{ll}\text { 1960, } & \text { Thomson } \\
\text { Reuters } & \end{array}$} & \multirow[t]{4}{*}{22000} & 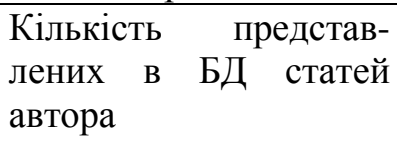 & \multirow[t]{4}{*}{ SNIP } \\
\hline & & & & Кількість цитувань & \\
\hline & & & & $\begin{array}{l}\text { Affiliation history (істо- } \\
\text { рія приналежності) }\end{array}$ & \\
\hline & & & & Умови передплати & \\
\hline
\end{tabular}

Джерело: сформовано авторами

WoS дозволяє організовувати пошук за ключовими словами, за окремими авторами і за організаціями (університетами), підключаючи при цьому потужний апарат аналізу знайдених результатів. Результат пошуку як за автором, так і за організацією дозволяє оцінити загальну кількість публікацій, кількість цитувань, h-індекс та інші показники. Розробник ресурсу Філадельфійський інститут наукової інформації. База даних доступна на умовах передплати*.

Визначено, що Thomson Reuters виступила ініціатором введення в обіг поняття імпактфактор, який створено в 1960 р. як спосіб вимірювання цінності журналу шляхом вирахування середнього числа цитувань за певний проміжок часу (два роки). Якщо імпакт-фактор становить 1,5 у 2018 р., то це означає, що в середньому статті, опубліковані в часописі протягом, скажімо, 2016 і 2017 р., були 1,5 рази процитовано в статтях 2018 р., виданих журналами з переліку індексованих.

Scopus $\epsilon$ найбільшою у світі реферативною базою даних та наукометричною платформою, яку створено у 2004 р. видавничою корпорацією Elsevier (заснованою у 1880 р., м. Амстердам, Нідерланди). База даних Scopus індексує наукові журнали, матеріали конференцій та серійні книжкові видання. Scopus індексує назви наукових видань 3 технічних, медичних та гуманітарних наук. Розробником та власником SciVerse Scopus є видавнича корпорація Elsevier. Вона $€$ комерційною базою даних і повна ії версія доступна тільки на умовах передплати. Однак існує можливість перегляду ресурсів бази даних Scopus в обмеженому режимі Scopus preview (доступно: кількість представлених у базі даних статей автора, h-index, кількість цитувань).*

\footnotetext{
* Джерело: http://library.kubg.edu.ua/informatsiya/naukovtsiam/naukometriia.html

* Джерело: http://library.lp.edu.ua/uk/naukometrychni-bazy
} 
Scopus містить понад 54 млн реферативних записів. У базі даних вже проіндексовано біля 22000 назв наукових журналів 5000 видавництв, 400 книжкових серій та 6,4 млн праць конференцій. Видання індексуються з різним хронологічним охопленням, найповажніші наукові часописи представлені архівами, починаючи з першого випуску першого тому. Наукометричний апарат Scopus забезпечує облік публікацій науковців і установ, у яких вони працюють, та статистику їх цитованості. База даних доступна на умовах передплати $[8,11]$.

SCImagoJournal \& CountryRank (SJR) - аналітичний портал, що надає наукові показники за журналами та країнами. Публікує рейтинги публікаційної активності і статистику цитування журналів і країн на основі інформації, що міститься в базі даних Scopus. SJR враховує такі показники: загальна кількість опублікованих статей, цитувань, зважені показники цитувань за роками, індекс Гірша. SJR - показник впливовості або престижності журналу. Висловлює середнє число цитат, отриманих у поточному році на статті, опубліковані в журналах за три попередні роки. Оновлюється два рази на рік. Ресурс знаходиться у вільному доступі [11].

Наявні на сьогодні усі наукометричні бази можна поділити на чотири рівні: вищий, середній, нижчий, звичайний. До вищого рівня належать такі науково-метричні бази, як бібліографічнореферативна база «Scopus (SciVerse Scopus)» (має свій аналітичний портал «Scimago Journal \& Country Rank») та пошукова платформа «Web of Science (Clarivate Analytics)», яка є сукупністю наступних баз даних наукової інформації: SSCI, SCIE, AHCI, «Index Chemicus» та низки інших. Традиційно вони вважаються найбільш якісними інструментами відбору публікацій матеріалів досліджень науковців. Якщо говорити про обсяги наповнення цих науково-бібліографічних баз даних, то ситуація виглядає таким чином. База даних «Scopus» покриває на сьогодні $[1,11]$ більшу частину фахових журналів усього світу, а база «Web of Science» значно відстає у кількості.* В умовах сьогодення міжнародна наукометрична база даних Scopus є лідером серед усіх наукометричних баз на ринку освітніх публікаційних послуг.

Установлено, що досліджувані наукометричні бази даних мають різні обсяги доступної для аналізу бібліографічної інформації, різні сервісні можливості. Поряд з доступністю і простотою пошуку бібліографічних даних варто також відзначити дієвість, зрозумілість та наочність представлення результатів [7, 12]. Крім НБД існує й інший шлях просування публікацій до читачів у Інтернет-просторі. Він пов'язаний з активною участю авторів у розміщенні наукових статей у таких інформаційних системах, як Google Scholar, ORCID, Research ID (табл. 2).

Таблиия 2

Загальна характеристика систем роботи з публікаціями за активної участі науковців

\begin{tabular}{|c|c|c|c|c|}
\hline № & Назва & Обсяг даних & Вихідні дані & Наукометрія \\
\hline 1 & $\begin{array}{l}\text { Google } \\
\text { Академія }\end{array}$ & $\begin{array}{l}\text { Платформа для електронних } \\
\text { журналів, бібліотек, репозиторіїв }\end{array}$ & $\begin{array}{l}\text { Пошукова, } \\
\text { наукометрична }\end{array}$ & $\begin{array}{l}\text { URL текстів, } \\
\text { індекс Гірша }\end{array}$ \\
\hline 2 & ORCID & $\begin{array}{l}\text { Платформа для електронних } \\
\text { журналів, різні системи ідентиф- } \\
\text { iкації та збору, зберігання і } \\
\text { експортування метаданих про } \\
\text { наукову діяльність фахівців }\end{array}$ & $\begin{array}{l}\text { пошукова, } \\
\text { наукометрична }\end{array}$ & $\begin{array}{l}\text { URL текстів, дані } \\
\text { про НДБ, } 3 \text { яких } \\
\text { отримана стаття }\end{array}$ \\
\hline 3 & $\begin{array}{l}\text { Research } \\
\text { ID }\end{array}$ & $\begin{array}{l}\text { Загальнодоступний простір для } \\
\text { створення } \\
\text { номеру }\end{array}$ & $\begin{array}{l}\text { пошукова, } \\
\text { наукометрична, } \\
\text { інформаційна }\end{array}$ & $\begin{array}{l}\text { URL текстів, дані } \\
\text { про НДБ, } 3 \text { яких } \\
\text { отримана стаття }\end{array}$ \\
\hline
\end{tabular}

Джерело: сформовано авторами

Таким чином, розміщення публікацій у наукових виданнях та Інтернеті варто віднести до елементів управління процесом, що містить цикл, у якому спільнота авторів або окремі науковці самі обирають засоби для розповсюдження результатів досліджень у журналах, репозитаріях або у комунікаційних Internet-системах. Часто це пов'язано 3 використанням таких інформаційних систем, як Google Scholar, ORCID та Research ID.

Установлено, що в аграрних закладах вищої освіти наявність інформаційно-аналітичної діяльності в умовах комплексних змін інформаційного середовища трансформує навчальну установу в центр соціальних комунікацій, що є важливим для проведення наукових досліджень. Управління цією діяльністю потребує виявлення та використання наявних наукових журналів, що входять до наукометричних баз даних Web of Science та Scopus у галузі сільського господарства, агрономії та біології (табл. 3). 
Таблиия 3

Зведені відомості наукових журналів, що входять до наукометричних баз даних Web of Science та Scopus серії «Сільське господарство, агрономія та біологія»

\begin{tabular}{|c|c|c|c|}
\hline $\begin{array}{c}\text { № } \\
\text { 3/II } \\
\end{array}$ & База даних & Основні категорії & Країни \\
\hline 1 & Web of Science & $\begin{array}{l}\text { Сільське господарство, біологічні } \\
\text { науки, агрономія і рослинництво, } \\
\text { зоологія, екологія }\end{array}$ & $\begin{array}{l}\text { * США, Велика Британія, Китай, } \\
\text { Нідерланди, Японія, Швейцарія, } \\
\text { Фінляндія, Чилі, Індія, Саудівська } \\
\text { Аравія, Австралія, Іран, Бразилія, } \\
\text { Польща, Італія, Чехія, Естонія, } \\
\text { Іспанія, Сгипет, Росія, Німеччина, } \\
\text { Болгарія, Ірландія, Латвія }\end{array}$ \\
\hline 2 & Scopus & $\begin{array}{l}\text { Сільське господарство, агрономія } \\
\text { i рослинництво, лісівництво, } \\
\text { садівництво, грунтознавство, } \\
\text { екологія, систематика }\end{array}$ & $\begin{array}{l}\text { ** Нідерланди, Велика Британія, } \\
\text { США, Польща, Франція, Естонія, } \\
\text { Швейцарія, Австралія }\end{array}$ \\
\hline
\end{tabular}

* периі 100 за індикатором рейтингу журналу SJR

** периі 100 за індикатором рейтингу журналу SiteScore

Після аналізу спеціалізованої літератури та сайтів-розробників міжнародних наукометричних систем відкритого доступу встановлено, що наукові журнали не входять у перші сто журналів за індикатором рейтингу журналу SJR та SiteScore відповідних наукометричних баз даних Web of Science та Scopus серії «Сільське господарство, агрономія та біологія».

Висновки. Інформаційне забезпечення наукового та освітнього процесу за рахунок публікацій наукових статей відповідного рівня посилює роль науково-педагогічних працівників у вирішенні завдань, що стоять перед аграрними вищими навчальними закладами на сучасному етапі. Найавторитетнішими у світі аналітичними політематичними базами даних $\epsilon$ Web of Science та Scopus. Тому одним із пріоритетних напрямів діяльності науково-педагогічних працівників аграрних вищих навчальних закладів освіти $€$ освоєння функцій навігації у світових наукометричних системах з метою сприяння трансформації з елемента дослідницької роботи в учасника науково-освітньої роботи та підвищення наукового статусу університету.

\section{Список використаних джерел}

1. Назоровець С.О. Квартальний підхід до проблеми стимулювання росту наукової продуктивності в університетах. Бібліотечний форум. 2016. № 2 (4). С. 10-12.

2. Колесникова Т.А. Интеграция украинской отраслевой научной периодики в мировое научно-информационное пространство: проблемы и решения. Наука та прогрес транспорту. Вісн. Дніпропетр. нац. ун-ту залізнич. транспорту ім. акад. В. Лазаряна. 2013. № 6. С. 7-22.

3. Подрезова М. О. Бібліографічна культура періодичного видання як напрям інформаційноаналітичної діяльності бібліотеки. Вісн. ОНУ. Сер.: Бібліотекознавство, бібліографознавство, книгознавство. 2013. Т. 18, вип. 1(9). С. 105-113.

4. Pruvot E.B., Claeys-Kulik A.L., Estermann T. Designing strategies for efficient funding of universities in Europe. DEFINE Project Paper. Brussels: European University Association. 2015. P. 20-22.

5. Ukraine Ranking Web of Universities [Електронний ресурс]. Режим доступу: http://www.webometrics.info/en/Europe/Ukraine.

6. Соловяненко Д. В. Політика індексації видань у наукометричних базах даних Web of Science та SciVerse Scorpus [Електронний ресурс]. Бібліотечний вісник. 2012. № 1. С. 6-21. Режим доступу до журн.: http://archive.nbuv.gov.ua/portal/Soc_Gum/Bib_visnyk/2012-1/02.pdf.

7. Франчук В. М. Ступінь представлення ВНЗ в глобальній мережі Інтернет [Електронний peсурс]. Науковий часопис НПУ імені М. П. Драгоманова. Серія № 2. Комп’ютерноорієнтовані системи навчання: збірник наукових праць. К.: НПУ імені М.П. Драгоманова, 2012. № 13 (20). C. 66-72. Режим доступу до журн.: http://www.vfranchuk.npu.edu.ua /images/files/statty 136_Webportal.pdf.

8. Ільченко М.Ю. Національний технічний університет України «КПІ» у світовому Webрейтингу [Електронний ресурс]. Київський політехнік. 2009. № 4. Режим доступу до статті : http://webometr.kpi.ua/node/1. 


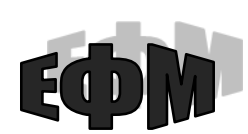

http://efm.vsau.org/

9. Majesticseo [Електронний ресурс]. Режим доступу: http://www.majesticseo.com.

10. Scimago Institutions Rankings. [Електронний ресурс]. Режим доступу: http://www.scimagoir.com.

11. Scopus [Електронний ресурс]. Режим доступу: http://www.scopus.com.

12. Elsevier [Електронний ресурс]. Режим доступу: http://www.elsevier.com.

\section{References}

1. Nazorovets, S.O. (2016). Kvartalnyi pidkhid do problemy stymuliuvannia rostu naukovoi produktyvnosti $\mathrm{v}$ universytetakh [Quarterly approach to the problem of stimulating the growth of scientific productivity in universities]. Bibliotechnyi forum - Library Forum, 2 (4), 10-12 [in Ukrainian].

2. Kolesnikova, T.A. (2013). Integracija ukrainskoj otraslevoj nauchnoj periodiki v mirovoe nauchno-informacionnoe prostranstvo: problemy i reshenija [Integration of Ukrainian sectoral scientific periodicals into the world scientific information space: problems and solutions]. Nauka ta prohres transportu. Visn. Dnipropetr. nats. un-tu zaliznych. transportu im. akad. V. Lazariana - Science and progress of transport. Visn. Dnepropetrovsk. nat. un-that rail. transport named afyer Acad. V. Lazaryan 6, 7-22 [in Ukrainian].

3. Podrezova, M.O. (2013). Bibliohrafichna kultura periodychnoho vydannia yak napriam informatsiino-analitychnoi diialnosti biblioteky [Bibliographic culture of periodicals as a direction of information-analytical activity of the library]. Visn. ONU. Ser.: Bibliotekoznavstvo, bibliohrafoznavstvo, knyhoznavstvo - Visn. ONU. Ser.: Library Studies, Bibliography, Books, 1(9), 105-113 [in Ukrainian].

4. Pruvot, E.B., Claeys-Kulik, A.L., Estermann, T. (2015). Designing strategies for efficient funding of universities in Europe. DEFINE Project Paper. Brussels: European University Association, pp. 20-22.

5. Ukraine Ranking Web of Universities. Retrieved from: http://www.webometrics.info /en/Europe/Ukraine.

6. Solovianenko, D.V. (2012). Polityka indeksatsii vydan u naukometrychnykh bazakh danykh Web of Science та SciVerse Scorpus [Policy of indexation of publications in science-based databases Web of Science та SciVerse Scorpus]. Bibliotechnyi visnyk - Library Bulletin, 1, 6-12 [in Ukrainian].

7. Franchuk, V.M. (2012). Stupin predstavlennia VNZ v hlobalnii merezhi Internet [Degree of representation of higher educational institutions in the global Internet]. Naukovyi chasopys NPU imeni M. P. Drahomanova. Seriia № 2. Kompiuternooriientovani systemy navchannia: zbirnyk naukovykh prats. K.: NPU imeni M.P. Drahomanova - Scientific journal of MP Dragomanov NPU. Series No. 2. ComputerCentered Learning Systems: A Collection of Scientific Papers. K.: NPU named after M.P. Drahomanov, 13 (20), 66-72 [in Ukrainian].

8. Ilchenko, M.Iu. (2009). Natsionalnyi tekhnichnyi universytet Ukrainy «KPI» u svitovomu Webreitynhu [National Technical University of Ukraine "KPI" in the world Web-rating]. Kyivskyi politekhnik - Kiev Polytechnic, 4 [in Ukrainian].

9. Majesticseo [Electronic resource]. Access mode: http://www.majesticseo.com.

10. Scimago Institutions Rankings [Electronic resource]. Access mode: http://www.scimagoir.com.

11. Scopus [Electronic resource]. Access mode: http://www.scopus.com.

12. Elsevier [Electronic resource]. Access mode: http://www.elsevier.com.

\section{Інформація про авторів}

МАЗУР Віктор Анатолійович - кандидат сільськогосподарських наук, доцент кафедри рослинництва, селекції та біоенергетичних культур, ректор Вінницького національного аграрного університету (21008, м. Вінниця, вул. Сонячна, 3).

МАЗУР Катерина Василівна - кандидат економічних наук, доцент, завідувач кафедри аграрного менеджменту Вінницького національного аграрного університету (21008, м. Вінниця, вул. Сонячна, 3).

ПАНЦИРЕВА Ганна Віталіївна - кандидат сільськогосподарських наук, старший викладач кафедри лісового, садово-паркового господарства, садівництва та виноградарства Вінницького національного аграрного університету (21008, м. Вінниця, вул. Сонячна 3, e-mail: apantsyreva@ukr.net).

MAZUR Viktor - Candidate of Agricultural Sciences, Associate Professor of the Department of Plant Production, Selection and Bioenergetic Crops, Rector of Vinnytsia National Agrarian University (21008, 3 Soniachna Str., Vinnytsia). 
MAZUR Kateryna - Candidate of Economic Sciences, Associate Professor, Head of the Department of Agrarian Management of Vinnytsia National Agrarian University (21008, 3 Soniachna Str., Vinnytsia).

PANTSYREVA Hanna - Candidate of Agricultural Sciences, Senior Lecturer of the Department of Forestry, landscape gardening, Horticulture and Viticulture of Vinnytsia National Agrarian University (21008, 3 Soniachna Str., Vinnytsia, e-mail: apantsyreva@ukr.net).

МАЗУР Виктор Анатольевич - кандидат сельскохозяйственных наук, доцент кафедры растениеводства, селекции и биоэнергетических культур, ректор Винницкого национального аграрного университета (21008, г. Винница, ул. Солнечная, 3).

МАЗУР Екатерина Васильевна - кандидат экономических наук, доцент, заведующая кафедрой аграрного менеджмента Винницкого национального аграрного университета (21008, г. Винница, ул. Солнечная, 3).

ПАНЦЫРЕВА Анна Витальевна - кандидат сельскохозяйственных наук, старший преподаватель кафедры лесного, садово-паркового хозяйства, садоводства и виноградарства Винницкого национального аграрного университета (21008, г. Винница, ул. Солнечная 3, e-mail: apantsyreva@ukr.net).

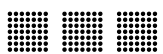

